\title{
Biochemical and metabolic profiles of Trichoderma strains isolated from common bean crops in the Brazilian Cerrado, and potential antagonism against Sclerotinia sclerotiorum
}

\author{
Fabyano Alvares Cardoso LOPES ${ }^{a}$, Andrei Stecca STEINDORFF ${ }^{a}$, \\ Alaerson Maia GERALDINE ${ }^{b}$, Renata Silva BRANDÃO ${ }^{a}$, Valdirene Neves MONTEIRO', \\ Murillo Lobo JÚNIOR ${ }^{b}$, Alexandre Siqueira Guedes COELHO ${ }^{d}$, Cirano José ULHOA ${ }^{a}$, \\ Roberto Nascimento SILVA ${ }^{e, *}$ \\ ${ }^{a}$ Department of Biochemistry and Molecular Biology, Federal University of Goiás (UFG), Goiânia, GO 74001-970, Brazil \\ brazilian Agricultural Research Corporation, Embrapa Rice and Beans, Rod. GO-462, Km 12, Santo Antônio de Goiás, CP 179, GO 75375-000, \\ Brazil \\ 'Universidade Estadual de Goiás, Unidade Universitária de Ciências Exatas e Tecnológicas da Universidade Estadual de Goiás-UnUCET, BR \\ 153, Km 98 Campus Henrique Santillo, Anápolis, GO 75000-000, Brazil \\ ${ }^{\mathrm{d}}$ School of Agronomy and Food Engineering, Federal University of Goiás (UFG), Goiânia, GO 74001-970, Brazil \\ e Department of Biochemistry and Immunology, School of Medicine, University of São Paulo, Ribeirão Preto, SP 14049-900, Brazil
}

\section{A R T I C L E I N F O}

Article history:

Received 21 September 2011

Received in revised form

12 April 2012

Accepted 25 April 2012

Available online 4 May 2012

Corresponding Editor:

Richard A. Humber

Keywords:

Antagonism

Biolog FF Microplate

CWDE

ITS

Mycoparasitism

Phenotype microarray

\section{A B S T R A C T}

Some species of Trichoderma have successfully been used in the commercial biological control of fungal pathogens, e.g., Sclerotinia sclerotiorum, an economically important pathogen of common beans (Phaseolus vulgaris L.). The objectives of the present study were (1) to provide molecular characterization of Trichoderma strains isolated from the Brazilian Cerrado; (2) to assess the metabolic profile of each strain by means of Biolog FF Microplates; and (3) to evaluate the ability of each strain to antagonize S. sclerotiorum via the production of cell wall-degrading enzymes (CWDEs), volatile antibiotics, and dual-culture tests. Among 21 isolates, we identified $42.86 \%$ as Trichoderma asperellum, $33.33 \%$ as Trichoderma harzianum, $14.29 \%$ as Trichoderma tomentosum, $4.76 \%$ as Trichoderma koningiopsis, and $4.76 \%$ as Trichoderma erinaceum. Trichoderma asperellum showed the highest CWDE activity. However, no species secreted a specific group of CWDEs. Trichoderma asperellum 364/01, T. asperellum 483/02, and T. asperellum 356/02 exhibited high and medium specific activities for key enzymes in the mycoparasitic process, but a low capacity for antagonism. We observed no significant correlation between CWDE and antagonism, or between metabolic profile and antagonism. The diversity of Trichoderma species, and in particular of T. harzianum, was clearly reflected in their metabolic profiles. Our findings indicate that the selection of Trichoderma candidates for biological control should be based primarily on the environmental fitness of competitive isolates and the target pathogen.

๑ 2012 The British Mycological Society. Published by Elsevier Ltd. All rights reserved.

\footnotetext{
* Corresponding author. Tel.: +55 163602 3260; fax: +55 1636336840 .

E-mail address: rsilva@fmrp.usp.br

1878-6146/\$ - see front matter ( 2012 The British Mycological Society. Published by Elsevier Ltd. All rights reserved. doi:10.1016/j.funbio.2012.04.015
} 


\section{Introduction}

The genus Trichoderma (Ascomycetes, Hypocreales) was first described by Persoon more than $200 \mathrm{y}$ ago, and consists of anamorphic fungi that mainly inhabit soil, organic matter, and decaying trees. Trichoderma species are among the most commonly distributed fungi in nature, and are found in ecosystems ranging from tundra to tropical. Their ability to survive in different regions can be attributed to diversified metabolic capabilities and natural competitive aggression.

Trichoderma spp. possess a wide variety of mechanisms for survival and proliferation, including physical attack and degradation of other fungi, and utilization of complex carbohydrates. Based on these characteristics, Trichoderma spp. are of considerable economic importance, and are used in commercial applications such as industrial enzyme production, heterologous protein expression, antibiotic production, and biocontrol of plant pathogenic fungi (reviewed by Benítez et al. 2004). The potential of Trichoderma for biocontrol was first recognized in the early 1930s. Since then, the genus has been extensively investigated as an antagonist of soil-borne plant pathogens, including Sclerotinia sclerotiorum (Lib.) De Bary, the causative agent of white mould. This economically important disease affects a wide range of hosts, and constitutes a major problem for centre-pivot irrigated production of common beans (Phaseolus vulgaris L.) in the Brazilian Cerrado during winter. The Brazilian Cerrado is a savanna-like region, covering more than $50 \%$ of the country. It is an important agricultural area, with common bean, soybean, and maize as the main crops. The biological control of S. sclerotiorum using Trichoderma species has proved successful in disease management strategies, by causing a decrease in the incidence of soil-borne fungal pathogens. Such biological control operates by several mechanisms, including competition for nutrients, production of volatile and nonvolatile antibiotics, and production of hydrolytic enzymes (reviewed by Benítez et al. 2004). Mycoparasitism appears to be a complex process, involving recognition of plant pathogens by chemotropism, coiling around the pathogen and appresorial formation, followed by production of cell wall-degrading enzymes (CWDEs) and peptaibols, mediated by heterotrimeric G-proteins and mitogenactivated protein (MAP) kinases (Druzhinina et al. 2011).

Fungi of the genus Trichoderma are prolific producers of hydrolytic enzymes, most of which appear to be chitinolytic (chitinases and $N$ - $\beta$-acetylglucosaminidases [NAGases]), glucanolytic ( $\beta$-1,3-glucanases), or proteases (De Marco \& Felix 2002; Almeida et al. 2007). The cell wall composition of plant pathogens is an important feature for inducing the production of these enzymes. The fungal cell wall is a complex structure, consisting of 80-90\% carbohydrate (mainly polysaccharides such as glucans, chitin, cellulose, and mannans) and 10-20\% proteins, lipids, ions, and organic pigments (Elad et al. 1983).

The mechanism of mycoparasitism has been extensively researched. Genomic and proteomic studies have been performed to identify new hydrolytic enzymes (Seidl et al. 2009; Monteiro et al. 2010); to elucidate the synergism between different hydrolytic enzymes, and also between hydrolytic enzymes and antibiotics (Reithner et al. 2005); and to investigate cell signalling during the formation of CWDEs (Silva et al. 2009).
Despite the different methodologies employed to explore the diversity of Trichoderma species and their potential for biological control, few physiological and molecular studies of CWDEs have been published. The aims of the present study were to characterize CWDE production at the molecular level, and to evaluate the antagonistic abilities and metabolic profiles of different Trichoderma strains isolated from the Brazilian Cerrado.

\section{Materials and methods}

\section{Microorganisms and culture conditions}

Twenty strains of Trichoderma spp. and a single strain of Sclerotinia sclerotiorum were isolated from different agroecosystems of the Brazilian Cerrado, cropped mainly with common beans (Embrapa Rice and Beans, Santo Antônio de Goiás, Brazil; Table 1). All isolates were obtained from 0 to $10 \mathrm{~cm}$ deep, GPS-georeferenced soil samples. The isolates were cultured either on potato dextrose agar (PDA) with $0.1 \%$ Triton $100-\mathrm{X}$, supplemented with $0.01 \%$ chloramphenicol, or on Komada's medium (Komada 1975), and stored on agar slants at $4{ }^{\circ} \mathrm{C}$ prior to use. The Trichoderma harzianum (ALL-42) isolate was provided by the Department of Biochemistry and Molecular Biology, Federal University of Goiás, Goiânia, Goiás, Brazil. All microorganisms were recovered on PDA plates at $28^{\circ} \mathrm{C}$ prior to use in the experimental procedures.

\section{DNA extraction and rDNA amplification/sequencing}

DNA was isolated from frozen and lyophilized mycelium, according to the methodology proposed by Raeder \& Broda (1985). The nuclear rRNA gene cluster containing the internal transcribed spacer (ITS) 1 and ITS2, and the 5.8S rRNA gene, was amplified using the primer combination ITS1 and ITS4, following the protocol described by White et al. (1990). Similarly, a portion of the translation elongation factor 1 alpha gene (tef1) (short fifth intron) was amplified using the primers tef1fw (5'-GTGAGCGTGGTATCACCA-TCG-3') and tef1rev (5'GCCATCCTTGGAGACCA-GC-3'), according to the methodology outlined by Kullnig-Gradinger et al. (2002). After amplification, the PCR product was subjected to gel electrophoresis in a $1 \%$ agarose gel, and purified using a protocol based on polyethylene glycol (PEG)-20\% PEG, $2.5 \mathrm{M} \mathrm{NaCl}, 80 \%$ ethanol, and pure ethanol. The purification product was used for sequencing in a reaction using a DYEnamic ${ }^{\mathrm{TM}}$ ET Terminator Cycle Sequencing Kit (GE Healthcare, USA), according to the manufacturer's instructions, and electrophoresed using the ABI Prism 3100 (Applied Biosystems).

\section{Analysis of sequence data}

DNA sequences were aligned using Clustal X v2.0.12. The terminal regions with poor alignment were manually removed using BioEdit v7.0.5.3, and the remaining portions were aligned together. Sequence analysis of the ITS and tef 1 amplicons was performed using the TrichOKEY 2.0 and TrichoBLAST tools available online at http://www.isth.info/. The sequences were deposited in GenBank (Table 1). 
Table 1 - Identification and sequence analysis of the Trichoderma strains used in this study.

\begin{tabular}{|c|c|c|c|c|c|}
\hline \multirow[t]{2}{*}{ Isolate } & \multicolumn{2}{|c|}{ Geolocalization } & \multirow[t]{2}{*}{ Identification $^{a}$} & \multicolumn{2}{|c|}{ Accession number } \\
\hline & & & & ITS 1 and 2 & tef1 \\
\hline $11 / 06$ & $-13^{\circ} 13^{\prime} 05.01^{\prime \prime}$ & $-41^{\circ} 22^{\prime} 36.50^{\prime \prime}$ & T. koningiopsis & HQ857120 & HQ857137 \\
\hline $11 / 11$ & $-13^{\circ} 13^{\prime} 05.01^{\prime \prime}$ & $-41^{\circ} 22^{\prime} 36.50^{\prime \prime}$ & T. asperellum & HQ857129 & HQ857151 \\
\hline $17 / 06$ & $-16^{\circ} 29^{\prime} 36.59^{\prime \prime}$ & $-49^{\circ} 18^{\prime} 06.13^{\prime \prime}$ & T. erinaceum & HQ857130 & HQ857133 \\
\hline 29/11 & $-23^{\circ} 25^{\prime} 29.57^{\prime \prime}$ & $-49^{\circ} 13^{\prime} 28.18^{\prime \prime}$ & T. tomentosum ${ }^{\mathrm{a}}$ & HQ857127 & HQ857149 \\
\hline $356 / 02$ & $-16^{\circ} 30^{\prime} 12.63^{\prime \prime}$ & $-49^{\circ} 17^{\prime} 27.13^{\prime \prime}$ & T. asperellum & HQ857123 & HQ857153 \\
\hline $357 / 01$ & $-16^{\circ} 30^{\prime} 07.57^{\prime \prime}$ & $-49^{\circ} 17^{\prime} 27.01^{\prime \prime}$ & T. asperellum & HQ857114 & HQ857134 \\
\hline $360 / 01$ & $-16^{\circ} 30^{\prime} 10.22^{\prime \prime}$ & $-49^{\circ} 17^{\prime} 37.12^{\prime \prime}$ & T. asperellum & HQ857131 & HQ857143 \\
\hline $362 / 02$ & $-16^{\circ} 30^{\prime} 09.80^{\prime \prime}$ & $-49^{\circ} 17^{\prime} 35.05^{\prime \prime}$ & T. asperellum & HQ857124 & HQ857132 \\
\hline $364 / 01$ & $-16^{\circ} 30^{\prime} 06.87^{\prime \prime}$ & $-49^{\circ} 17^{\prime} 22.10^{\prime \prime}$ & T. asperellum & HQ857112 & HQ857144 \\
\hline $364 / 02$ & $-16^{\circ} 30^{\prime} 06.87^{\prime \prime}$ & $-49^{\circ} 17^{\prime} 22.10^{\prime \prime}$ & T. tomentosum ${ }^{\mathrm{a}}$ & HQ857116 & HQ857147 \\
\hline 397/01 & $-18^{\circ} 56^{\prime} 50.55^{\prime \prime}$ & $-47^{\circ} 29^{\prime} 46.05^{\prime \prime}$ & T. harzianum ${ }^{\mathrm{a}}$ & HQ857108 & HQ857139 \\
\hline 400/01 & $-18^{\circ} 56^{\prime} 29.60^{\prime \prime}$ & $-47^{\circ} 29^{\prime} 46.05^{\prime \prime}$ & T. asperellum & HQ857121 & HQ857150 \\
\hline $468 / 02$ & $-15^{\circ} 39^{\prime} 48.08^{\prime \prime}$ & $-47^{\circ} 20^{\prime} 41.57^{\prime \prime}$ & T. asperellum & HQ857128 & HQ857152 \\
\hline $475 / 02$ & $-15^{\circ} 39^{\prime} 48.08^{\prime \prime}$ & $-47^{\circ} 20^{\prime} 41.57^{\prime \prime}$ & T. harzianum & HQ857115 & HQ857145 \\
\hline $476 / 01$ & $-15^{\circ} 39^{\prime} 48.08^{\prime \prime}$ & $-47^{\circ} 20^{\prime} 41.57^{\prime \prime}$ & T. harzianum & HQ857109 & HQ857140 \\
\hline $476 / 02$ & $-15^{\circ} 39^{\prime} 48.08^{\prime \prime}$ & $-47^{\circ} 20^{\prime} 41.57^{\prime \prime}$ & T. tomentosum ${ }^{\mathrm{a}}$ & HQ857119 & HQ857146 \\
\hline $479 / 02$ & $-15^{\circ} 39^{\prime} 48.08^{\prime \prime}$ & $-47^{\circ} 20^{\prime} 41.57^{\prime \prime}$ & T. harzianum ${ }^{\mathrm{a}}$ & HQ857118 & HQ857142 \\
\hline $483 / 02$ & $-15^{\circ} 39^{\prime} 48.08^{\prime \prime}$ & $-47^{\circ} 20^{\prime} 41.57^{\prime \prime}$ & T. asperellum & HQ857110 & HQ857154 \\
\hline $487 / 02$ & $-15^{\circ} 39^{\prime} 48.08^{\prime \prime}$ & $-47^{\circ} 20^{\prime} 41.57^{\prime \prime}$ & T. harzianum & HQ857113 & HQ857138 \\
\hline 494/01 & $-15^{\circ} 39^{\prime} 48.08^{\prime \prime}$ & $-47^{\circ} 20^{\prime} 41.57^{\prime \prime}$ & T. harzianum & HQ857125 & HQ857155 \\
\hline ALL-42 & $-17^{\circ} 46^{\prime} 02.25^{\prime \prime}$ & $-50^{\circ} 56^{\prime} 24.00^{\prime \prime}$ & T. harzianum ${ }^{\mathrm{a}}$ & HQ857122 & HQ857136 \\
\hline
\end{tabular}

a TrichoBLAST identification using ITS 1-2 and tef1 5th intron and confirmed using Bayesian analysis with tef1.

Phylogenetic reconstruction using the Bayesian approach was performed according to Jaklitsch et al. (2006), through tef1, using Mr Bayes v3.1.2. The best model proposed by $\mathrm{Mr}$ Modeltest v2.3 based on AIC was a Hasegawa-Kishino-Yano $(\mathrm{HKY})+$ gamma distribution (G) model. Markov chain Monte Carlo (mcmc) sampling was performed with $1 \times 10^{6}$ generations. The Bayesian posterior probabilities (pp) were obtained from the $50 \%$ majority rule consensus of 15310 trees (one tree sampled from each of 10 generations), after removal of 4000 first trees using the 'burn-in' process. The tree was rooted with the tef1 sequence of the OY6607 (FJ619248.1) strain from Trichoderma longibrachiatum.

\section{Metabolic profile analysis}

The global carbon assimilation profiles were evaluated using the Biolog Phenotype MicroArray technique (Druzhinina et al. 2006), with the Biolog FF Microplate. The Trichoderma strains were grown in $2 \%$ malt extract agar under ambient laboratory conditions with diffuse daylight at $25^{\circ} \mathrm{C}$. The inocula were prepared after conidial maturation ( $2-3 \mathrm{~d}$ ), by rolling a sterile, wetted cotton swab in the area containing the conidia. The conidia were suspended in $16 \mathrm{ml}$ of sterile phytagel (0.25\% Phytagel, $0.03 \%$ Tween 40) in disposable borosilicate tubes $(20 \mathrm{~mm} \times 150 \mathrm{~mm})$. The spore solution was mixed manually for $5 \mathrm{~s}$ and adjusted to a $\mathrm{T}_{590}$ of $75 \% \pm 3 \%$. Next, $100 \mu \mathrm{l}$ of spore solution was transferred to each well of a Biolog FF Microplate. The microplates were kept in the dark at $25^{\circ} \mathrm{C}$. The mycelial growth was assessed by measuring the $A_{750}$ at $12 \mathrm{~h}, 24 \mathrm{~h}$, and $48 \mathrm{~h}$. Each Trichoderma strain was analyzed in three independent experiments, using different inocula. Cluster analysis was performed using Mev v.4.6.1, with Pearson's product-moment correlation coefficient as a similarity statistic, and average linkage clustering as the linkage method.

\section{Volatile metabolites from Trichoderma spp. against Sclerotinia sclerotiorum}

Separate plates containing PDA medium were inoculated in the centre with a 5-mm diameter mycelial disc containing $S$. sclerotiorum or the different Trichoderma strains. The lids were removed, and each plate was inverted and placed on top of another plate. Each plate base was then sealed with a double layer of parafilm. The plates were kept in a biochemical oxygen demand (BOD) incubator at $25^{\circ} \mathrm{C}$ with a 12 -h photoperiod. The pathogen was grown in the upper plate to avoid interference by spores in the lower plate inoculated with the antagonists. The pathogen colony diameter was estimated when the pathogen completely covered the control plate without Trichoderma, and was converted to the percentage of inhibition in relation to the control plate. The experiment was replicated three times for each Trichoderma strain. The results were compared using analysis of variance (ANOVA) and means separation by the Scott-Knott test ( $\alpha=5 \%$ ), with SISVAR software. Pearson's coefficient was estimated by correlation analysis, using the STATISITICA 8.0 software and Pearson's correlation.

\section{Dual-culture test}

To evaluate the antagonism of Trichoderma strains against Sclerotinia sclerotiorum, 5-mm diameter discs of PDA medium were taken from the edge of actively growing colonies of fresh fungal cultures, and placed on the surface of a fresh PDA plate 
at a spacing of $4 \mathrm{~cm}$. The plates were incubated in a BOD at $25^{\circ} \mathrm{C}$, with a 12 -h photoperiod. The evaluation was performed when the pathogen completely covered the control plate without Trichoderma.

The evaluation of antagonism was carried out according to the classification proposed by Bell et al. (1982): grade 1, Trichoderma grows on the pathogen and occupies the entire surface of the medium; grade 1.5, Trichoderma grows on $87.5 \%$ of the surface of the medium; grade 2, Trichoderma grows on $\sim 66.6 \%$ of the surface of the medium; grade 2.5 , Trichoderma grows on $\sim 62.5 \%$ of the surface of the medium; grade 3 , Trichoderma occupies $\sim 50.0 \%$ of the surface of the medium; grade 3.5 , Trichoderma grows on $\sim 37.5 \%$ of the surface of the medium; grade 4 , Trichoderma grows on $\sim 33.3 \%$ of the surface of the medium; and grade 5, Trichoderma does not grow and the pathogen occupies the entire surface of the medium. The experiment was replicated three times for each Trichoderma strain, and the results were compared by ANOVA as described previously.

\section{Enzyme production and enzymatic assays}

For hydrolytic enzyme production, 3-mm diameter mycelial discs containing Trichoderma strains cultured on MYG solid medium (malt extract, $0.5 \%$; yeast extract, $0.25 \%$; glucose, $1 \%$; and agar, $1.5 \%$ ) were inoculated into TLE medium $\left(\mathrm{CaCl}_{2} \cdot 2 \mathrm{H}_{2} \mathrm{O}, 0.3 \mathrm{~g} \mathrm{l}^{-1} ; \mathrm{KH}_{2} \mathrm{PO}_{4}, 2.0 \mathrm{~g} \mathrm{l}^{-1} ;\left(\mathrm{NH}_{4}\right)_{2} \mathrm{SO}_{4}, 1.4 \mathrm{~g} \mathrm{l}^{-1}\right.$; $\mathrm{MgSO}_{4} \cdot 7 \mathrm{H}_{2} \mathrm{O}, 0.3 \mathrm{~g} \mathrm{l}^{-1}$; urea, $0.3 \mathrm{~g} \mathrm{l}^{-1}$; peptone, $1.0 \mathrm{~g} \mathrm{l}^{-1}$; and $0.1 \%$ trace elements $\left[\mathrm{Fe}^{2+}, \mathrm{Zn}^{2+}, \mathrm{Mn}^{2+}, \mathrm{Cu}^{2+}\right]$ solution, $0.1 \%$ ) containing lyophilized and macerated cell walls of Sclerotinia sclerotiorum $(0.5 \%)$ as the carbon and nitrogen source. The cultures were grown in 125-ml conical flasks with constant shaking $(120 \mathrm{rpm})$ at $28^{\circ} \mathrm{C}$. After $48 \mathrm{~h}$, the mycelium was harvested by filtration through filter paper, and the culture filtrate was used as a source of enzymes. The cell wall of S. sclerotiorum was obtained by culturing $\mathrm{S}$. sclerotiorum in MYG liquid medium at $28{ }^{\circ} \mathrm{C}$ with constant shaking (180 rpm). After $15 \mathrm{~d}$, the mycelium was recovered by filtration and washed thoroughly with distilled water. Following inactivation by autoclave, the mycelium was frozen and ground in liquid nitrogen.

The chitinase, NAGase, acid phosphatase, $\beta$-glucosidase, $\alpha$ mannosidase, and $\alpha$-L-arabinofuranosidase (ABFase) activities were determined using $p$-nitrophenyl-derived substrates: $p$-nitrophenyl-NN-diacetylchitobiose ( $p$-NPNNDC) $(2.5 \mathrm{mM})$; $p$-nitrophenyl- $\beta$-N-acetylglucosamine ( $p$-NPNAG) $(5 \mathrm{mM})$; $p$-nitrophenyl-phosphate ( $p$-NPP) $(5 \mathrm{mM}) ; p$-nitrophenyl- $\beta$-Dglucopyranoside ( $p$-NPGluc) (5 mM); $p$-nitrophenyl- $\alpha$-D-mannopyranoside ( $p$-NPMan) (5 mM); and $p$-nitrophenyl- $\alpha$-L-arabinopyranoside ( $p$-NPABF) (5 mM) (Sigma-Aldrich, St. Louis, USA). The reactions were carried out in microplate assay format. The assay mixtures contained $10 \mu$ l of enzyme solution, $40 \mu \mathrm{l}$ of $p$-nitrophenyl-derived solution, and $100 \mu \mathrm{l}$ of $50 \mathrm{mM}$ sodium acetate buffer. The mixtures were buffered at $\mathrm{pH} 4.8$ (acid phosphatase/ABFase), pH 5.0 (chitinase), pH 5.5 (NAGase), and pH 6.0 ( $\beta$-glucosidase/ $\alpha$-mannosidase). After incubation at $37^{\circ} \mathrm{C}$ for $15 \mathrm{~min}$, the reaction was stopped by the addition of $100 \mu \mathrm{l}$ of $\mathrm{Na}_{2} \mathrm{CO}_{3}(1 \mathrm{M})$. The amount of $p$-nitrophenol was determined spectrophotometrically at $A_{405}$. One unit of enzyme activity was defined as the amount of enzyme necessary to release $1 \mu \mathrm{mol}$ of $p$-nitrophenol per minute.
The lipase activity was determined using $p$-nitrophenylpalmitate ( $p$-NPPa) (Sigma-Aldrich, St. Louis, USA) as a substrate, at a concentration of $5 \mathrm{mM}$ in acetonitrile. The assay mixtures contained $100 \mu \mathrm{l}$ of enzyme solution, $20 \mu \mathrm{l}$ of $p$ NPPa solution, and $100 \mu \mathrm{l}$ of $0.1 \mathrm{~mol} \mathrm{l}^{-1}$ sodium phosphate buffer ( $\mathrm{pH} 7.0$ ) containing $0.27 \mathrm{M} \mathrm{NaCl}$ and $0.9 \% \mathrm{v} / \mathrm{v}$ Triton $\mathrm{X}-100$. After incubation at $37{ }^{\circ} \mathrm{C}$ for $30 \mathrm{~min}$, the mixtures were transferred to a domestic microwave oven and irradiated for $30 \mathrm{~s}$ on medium-low power to stop the reaction.

The $\beta$-1,3-glucanase activity was determined using laminarin (Sigma-Aldrich, St. Louis, USA) as a substrate, at a concentration of $0.75 \% \mathrm{w} / \mathrm{v}$ in sodium acetate buffer $(50 \mathrm{mM}, \mathrm{pH}$ 5.0) (Ramada et al. 2010). The assay mixtures contained $10 \mu \mathrm{l}$ of enzyme solution and $20 \mu \mathrm{l}$ of laminarin solution. After incubation at $50^{\circ} \mathrm{C}$ for $10 \mathrm{~min}, 100 \mu \mathrm{l}$ of 3,5-dinitrosalicylic acid (DNS) were added, and the mixtures were reincubated at $95{ }^{\circ} \mathrm{C}$ for $5 \mathrm{~min}$. The amount of reducing sugar was determined spectrophotometrically at $A_{540}$. One unit of enzyme activity was defined as the amount of enzyme necessary to release $1 \mu \mathrm{mol}$ of reducing sugar per minute.

The proteases activities were determined using azocasein (Sigma-Aldrich, St. Louis, USA) as a substrate, at a concentration of $0.25 \% \mathrm{w} / \mathrm{v}$ in $50 \mathrm{mM}$ phosphate buffer (pH 5.0), $50 \mathrm{mM}$ citrate buffer ( $\mathrm{pH} 7.0)$, or $50 \mathrm{mM}$ Tris- $\mathrm{HCl}(\mathrm{pH}$ 8.5) for acid, neutral, and basic proteases, respectively. The assay mixtures contained $20 \mu \mathrm{l}$ of enzyme solution, $40 \mu \mathrm{l}$ of azocasein solution, and $40 \mu \mathrm{l}$ of the respective buffer. After incubation at $37^{\circ} \mathrm{C}$ for $30 \mathrm{~min}, 100 \mu \mathrm{l}$ of trichloroacetic acid (TCA) $10 \% \mathrm{w} / \mathrm{v}$ were added, and the mixtures were reincubated at $4{ }^{\circ} \mathrm{C}$ for $10 \mathrm{~min}$. The samples were centrifuged at $2500 \mathrm{rpm}$ for 30 min, after which $100 \mu$ l of supernatant were transferred to another microplate containing $100 \mu \mathrm{l}$ of $\mathrm{NaOH}(1 \mathrm{M})$. The amount of protease was determined spectrophotometrically at $A_{450}$. One unit of enzyme activity was defined as the amount of enzyme necessary to elevate 1 unit of absorbance per minute.

The protein concentrations of the samples were determined using the Bradford assay (Bradford 1976), with bovine serum albumin (BSA; Sigma-Aldrich, St. Louis, USA) as a standard.

All enzyme assays were replicated three times for each sample. The results were compared using ANOVA and means separation by the Scott-Knott test ( $\alpha=5 \%$ ), with SISVAR software. Only enzyme assays with a standard deviation (SD) of $<20 \%$ were accepted.

\section{Results}

\section{Molecular identification}

The isolates were identified at the species level using the molecular tool TrichOKEY 2.0, based on the ITS sequence. When this was not possible, TrichoBLAST was used for species identification, using sequences ITS1 and ITS2, and the tef1 5th intron, as indicated in Table 1. The identification was confirmed by Bayesian analysis of the tef1 cluster (Fig 1). We identified nine (42.86\%) out of the 21 isolates as Trichoderma asperellum, seven (33.33\%) as Trichoderma harzianum, three (14.29\%) as Trichoderma tomentosum, one (4.76 \%) as 


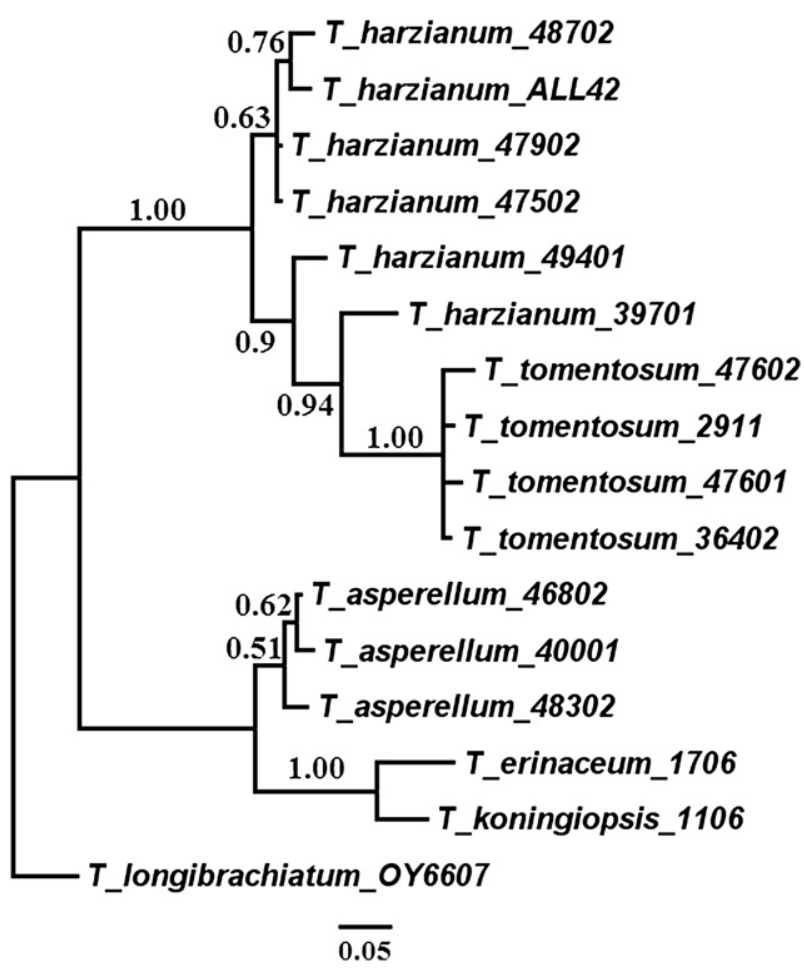

Fig 1 - Consensus tree obtained by Bayesian analysis of the tef1 sequences with the HKY + G model. Trichoderma asperellum strains 11/11, 356/02, 357/01, 360/01, 362/02, and $364 / 01$ are represented by $T$. asperellum 468/02, because they share the same tef 1 sequence.

Trichoderma koningiopsis, and one (4.76 \%) as Trichoderma erinaceum (Table 1).

\section{Metabolic profile analysis}

Separate analyses were performed for mycelial production, by measuring the turbidity $\left(A_{750}\right)$, at $12 \mathrm{~h}, 24 \mathrm{~h}$, and $48 \mathrm{~h}$. Fig 2 shows the turbidity data at $48 \mathrm{~h}$, representing mycelial growth and assimilation of the test substrate. Cluster analysis separated the strains into three major groups (Pearson's coefficient $>0.8$ ): cluster I, a separate group of Trichoderma asperellum and one strain of Trichoderma tomentosum; cluster II, Trichoderma erinaceum, Trichoderma koningiopsis, T. tomentosum, and Trichoderma harzianum; and cluster III, two strains of T. harzianum. Additionally, two strains of T. harzianum did not group. Cluster I was 70-80 \% supported by bootstrap analysis with 1000 iterations, while clusters II and III were 0-50\% supported. Cluster II included two sub-groups, the first containing T. koningiopsis 11/06 and T. erinaceum 17/06 (80-90\% supported by bootstrap analysis), and the second containing T. tomentosum 364/02, T. harzianum 476/01, and T. harzianum 494/01 (90-100\% supported by bootstrap analysis) (data not shown). The groups containing T. harzianum did not correlate with the groups generated by phylogenetic analysis, indicating variability among $T$. harzianum species (as previously described by Druzhinina et al. 2010). Furthermore, internal clustering within $\mathrm{T}$. harzianum showed four separate groups (Pearson's coefficient $>0.8$ ), indicating a metabolic versatility within the species. Our data demonstrate the importance of metabolic profile analysis in identification of Trichoderma strains, and also in elucidation of global species relationships.

The mycelial growth assessment shown in Fig 2 includes the analysis of specific metabolic properties of Trichoderma species, as indicated by the most assimilable carbon sources. In general, all species grew best on the following carbon sources: D-glucose, glycerol, D-mannitol, $\mathrm{N}$-acetyl-D-glucosamine, i-erythritol, gentiobiose, D-arabitol, D-fructose, dextrin, and xylose. By contrast, poor or no growth was observed on glucuronamide, N-acetyl-D-galactosamine, sedoheptulosan, p-hydroxyphenyl-acetic acid, L-pyroglutamic acid, L-fucose, rhamnose, and D-psicose. The highest mycelial growth was shown by $T$. asperellum and $T$. tomentosum 476/02, followed by T. harzianum, Trichoderma gamsii, T. tomentosum, T. koningiopsis, and T. erinaceum. Specific carbon source assimilation was detected only for $\mathrm{T}$. asperellum and T. tomentosum $476 / 02$, which was the only one to assimilate D-melezitose.

\section{Potential for antagonistic activity}

The antagonistic potential of Trichoderma strains was assessed by the inhibition of pathogen growth through the production of volatile metabolites, and also by the dual-culture test. Strains Trichoderma asperellum 11/11 and Trichoderma harzianum ALL-42 showed the highest inhibition ( $>50 \%$ ) of Sclerotinia sclerotiorum growth. Most strains showed moderate inhibition ( 30\%), while only three strains-Trichoderma tomentosum 364/02, T. asperellum 400/01, and T. tomentosum 476/02-showed inefficient $(<10 \%)$ inhibition (Table 2$)$. In the dual-culture test, strains T. asperellum 11/11, T. harzianum ALL-42, and T. tomentosum 29/11 exhibited the lowest Bell's classification scores (indicating highly efficient antagonism) (Table 2). Most of the remaining strains showed moderately efficient or efficient antagonism against $S$. sclerotiorum, with only three strains- $T$. asperellum 356/02, T. harzianum 475/02, and T. harzianum 479/ 02-showing inefficient antagonism (Table 2). We detected no statistical difference in growth inhibition of S. sclerotiorum between species (Table 2). Furthermore, we detected a positive correlation between volatile metabolite production and antagonism against $S$. sclerotiorum $(r=0.55 ; p=0.0069$ ) (data not shown). This finding indicates that efficient antagonistic strains are efficient inhibitors of S. sclerotiorum growth, through the production of volatile metabolites.

\section{CWDE analysis}

In general, in the presence of Sclerotinia sclerotiorum cell wall, all of the Trichoderma strains secreted a number of different CWDEs, including chitinase, NAGase, proteases, $\beta-1,3-$ glucanase, lipase, acid phosphatase, $\alpha$-mannosidase, ABFase, and $\beta$-glucosidase (Fig 3). The highest chitinase specific activity was exhibited by Trichoderma asperellum 356/02 (1.067 U $\left.\cdot \mathrm{mg}^{-1}, p<0.001\right)$, followed by Trichoderma harzianum ALL-42 (0.626 U. $\left.\mathrm{mg}^{-1}\right)$, T. harzianum 475/02 (0.460 U. $\mathrm{mg}^{-1}$ ), T. harzianum 487/02 (0.452 U. $\left.\mathrm{mg}^{-1}\right)$, and $\mathrm{T}$. asperellum 483/02 $\left(0.438 \mathrm{U} \cdot \mathrm{mg}^{-1}\right)$. The highest NAGase specific activity was exhibited by T. asperellum 468/02 (6.148 U. $\mathrm{mg}^{-1}, p<0.001$ ). The highest acid phosphatase specific activity was exhibited by T. asperellum 357/01 (4.017 $\left.\mathrm{U} \cdot \mathrm{mg}^{-1}, p<0.001\right)$, followed by 


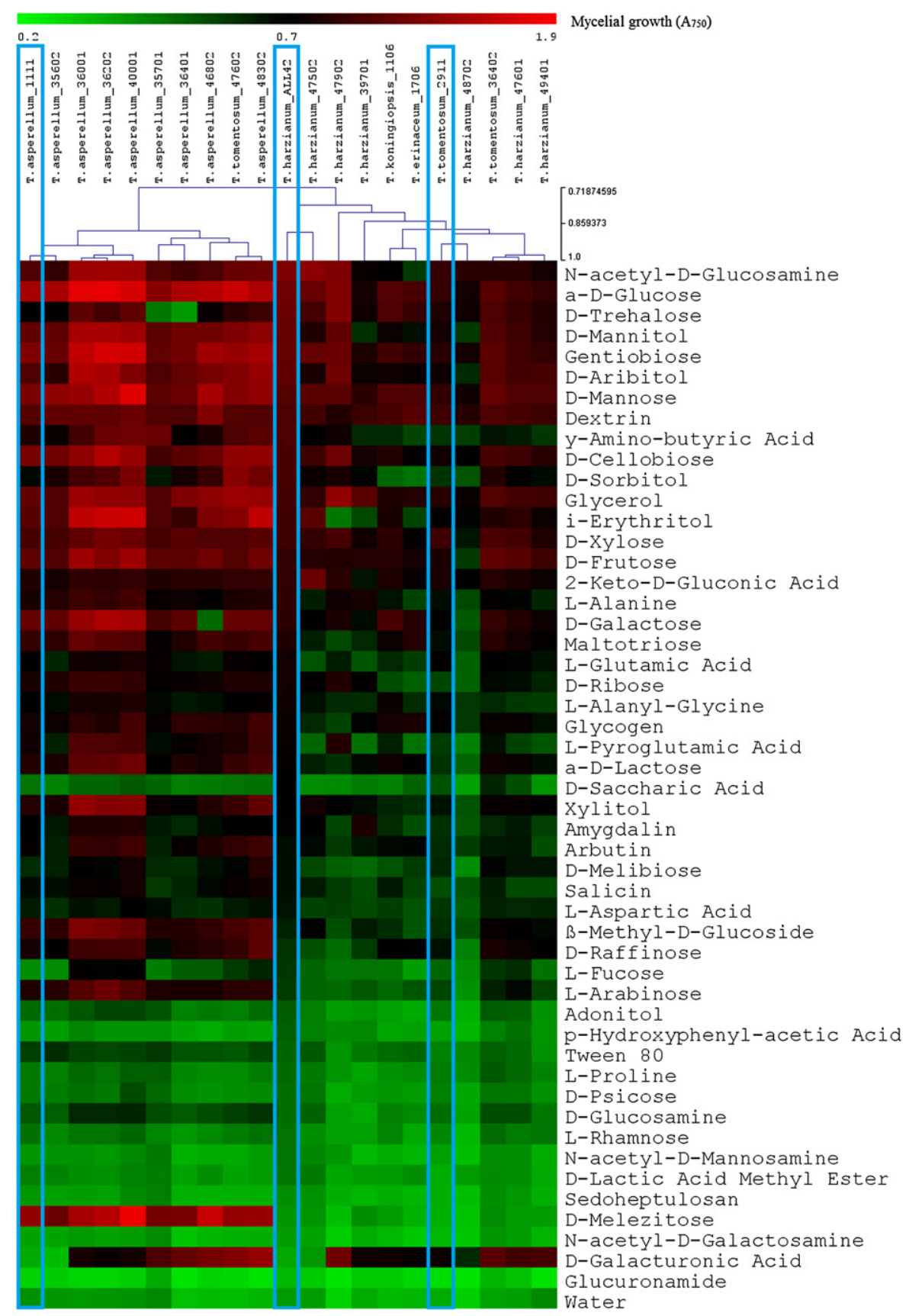

Fig 2 - Global carbon assimilation profiles of Trichoderma strains at $48 \mathrm{~h}$. The mycelial growth was assessed by measuring the $A_{750}$. Low mycelial growth is represented by light green colour $\left(0.2 \leq A_{750} \leq 0.5\right)$ and high mycelial growth is represented by light red colour $\left(1.0 \leq A_{750} \leq 1.9\right)$. Intermediate mycelial growth is represented by black colour $\left(0.5 \leq A_{750} \leq 1.0\right)$. Cluster analyses were based in the grown on fonts of carbon evaluated, with Pearson's product-moment correlation coefficient as a similarity statistic, and average linkage clustering as the linkage method. Each Trichoderma strain was analyzed in three independent experiments, with different inocula; data with a mean error of $<\mathbf{1 0} \%$ are shown. Blue rectangles indicate isolates with the highest production of antagonistic volatile metabolites.

T. asperellum 400/01 (3.782 U $\left.\cdot \mathrm{mg}^{-1}, p<0.001\right)$, T. harzianum 487/ $02\left(2.364 \mathrm{U} \cdot \mathrm{mg}^{-1}\right), \mathrm{T}$. harzianum 479/02 (1.638 U. $\left.\mathrm{mg}^{-1}\right)$, and T. asperellum 364/01 (1.457 $\left.\mathrm{U} \cdot \mathrm{mg}^{-1}\right)$. The highest $\beta$-glucosidase specific activity was exhibited by $T$. asperellum 364/01 (1.736 U. $\mathrm{mg}^{-1}, p<0.001$ ), followed by $\mathrm{T}$. asperellum $360 / 01$ (1.015 U.mg $\mathrm{m}^{-1}, p<0.001$ ), Trichoderma koningiopsis 11/06 (0.784 U.mg $\left.{ }^{-1}\right)$, T. harzianum 494/01 (0.763 U. $\left.\mathrm{mg}^{-1}\right)$, and
Trichoderma erinaceum 17/06 (0.698 U $\left.\cdot \mathrm{mg}^{-1}\right)$. No strain showed exceptionally high specific activity with respect to ABFase, $\alpha$ mannosidase, or lipase.

The highest $\beta$-1,3-glucanase specific activity was exhibited by $\mathrm{T}$. asperellum 483/02 (3156 U. $\mathrm{mg}^{-1}, p<0.001$ ), followed by $\mathrm{T}$. asperellum $364 / 01$ (3120 $\left.\mathrm{U} \cdot \mathrm{mg}^{-1}, p<0.001\right)$, T. asperellum 468/02 (2703 U. $\left.\mathrm{mg}^{-1}, p<0.001\right)$, T. erinaceum 17/06 (2669 U. $\mathrm{mg}^{-1}$ ), 
Table 2 - Antagonism and growth inhibition of S. sclerotiorum by Trichoderma strains.

\begin{tabular}{|c|c|c|c|c|c|}
\hline Strains & Species & & & by $\mathrm{v}$ & $\begin{array}{l}n \\
\mathrm{~s}^{* *}(\%)\end{array}$ \\
\hline $11 / 06$ & T. koningiopsis & 2.00 & $\mathrm{~b}$ & 40.67 & e \\
\hline $11 / 11$ & T. asperellum & 1.33 & $\mathrm{a}$ & 55.50 & e \\
\hline $17 / 06$ & T. erinaceum & 3.00 & c & 40.00 & e \\
\hline 29/11 & T. tomentosum & 1.00 & a & 31.67 & e \\
\hline $356 / 02$ & T. asperellum & 3.33 & $d$ & 29.33 & e \\
\hline $357 / 01$ & T. asperellum & 2.67 & c & 32.00 & e \\
\hline $360 / 01$ & T. asperellum & 1.67 & $\mathrm{~b}$ & 33.33 & e \\
\hline $362 / 02$ & T. asperellum & 2.00 & $\mathrm{~b}$ & 20.00 & $\mathrm{f}$ \\
\hline $364 / 01$ & T. asperellum & 2.00 & $\mathrm{~b}$ & 20.67 & $\mathrm{f}$ \\
\hline $364 / 02$ & T. tomentosum & 2.67 & c & 8.33 & $\mathrm{f}$ \\
\hline 397/01 & T. harzianum & 3.00 & c & 26.33 & $\mathrm{f}$ \\
\hline 400/01 & T. asperellum & 3.00 & c & 8.33 & $\mathrm{f}$ \\
\hline $468 / 02$ & T. asperellum & 2.00 & $\mathrm{~b}$ & 25.00 & $\mathrm{f}$ \\
\hline $475 / 02$ & T. harzianum & 4.00 & $d$ & 15.00 & $\mathrm{f}$ \\
\hline $476 / 01$ & T. harzianum & 3.00 & c & 24.00 & $\mathrm{f}$ \\
\hline $476 / 02$ & T. tomentosum & 2.00 & $\mathrm{~b}$ & 8.33 & $\mathrm{f}$ \\
\hline $479 / 02$ & T. harzianum & 3.67 & $d$ & 23.33 & $\mathrm{f}$ \\
\hline 483/02 & T. asperellum & 2.67 & c & 16.67 & $\mathrm{f}$ \\
\hline 487/02 & T. harzianum & 3.00 & c & 18.67 & $\mathrm{f}$ \\
\hline 494/01 & T. harzianum & 2.00 & $\mathrm{~b}$ & 21.67 & $\mathrm{f}$ \\
\hline ALL-42 & T. harzianum & 1.00 & $\mathrm{a}$ & 60.00 & e \\
\hline
\end{tabular}

T. asperellum 360/01 (2423 $\left.\mathrm{U} \cdot \mathrm{mg}^{-1}\right)$, and T. asperellum 356/02 $\left(2413 \mathrm{U} \cdot \mathrm{mg}^{-1}\right)$.

The highest proteolytic specific activity (acid, neutral, basic) was exhibited by T. asperellum 364/01 (4.960 U. $\mathrm{mg}^{-1}$, $\left.12.770 \mathrm{U} \cdot \mathrm{mg}^{-1}, 18.770 \mathrm{U} \cdot \mathrm{mg}^{-1}\right)$, followed by $\mathrm{T}$. harzianum 475/02 (4.662 U. $\left.\mathrm{mg}^{-1}, 7.753 \mathrm{U} \cdot \mathrm{mg}^{-1}, 8.077 \mathrm{U} \cdot \mathrm{mg}^{-1}\right)$, T. harzianum 476/01 (4.414 U. $\left.\mathrm{mg}^{-1}, 7.063 \mathrm{U} \cdot \mathrm{mg}^{-1}, 2.587 \mathrm{U} \cdot \mathrm{mg}^{-1}\right)$, Trichoderma tomentosum 476/02 (4.335 U. $\mathrm{mg}^{-1}, 7.538 \mathrm{U} \cdot \mathrm{mg}^{-1}$, $\left.6.765 \mathrm{U} \cdot \mathrm{mg}^{-1}\right), \quad \mathrm{T}$. harzianum ALL-42 (3.353 U. $\mathrm{mg}^{-1}$, $\left.7.813 \mathrm{U} \cdot \mathrm{mg}^{-1}, 4.406 \mathrm{U} \cdot \mathrm{mg}^{-1}\right)$, and $\mathrm{T}$. asperellum $483 / 02$ $\left(2.744 \mathrm{U} \cdot \mathrm{mg}^{-1}, 7.143 \mathrm{U} \cdot \mathrm{mg}^{-1}, 8.832 \mathrm{U} \cdot \mathrm{mg}^{-1}\right)$. Comparison of the protease profiles revealed no similarity between acid and basic proteases $(p>0.05)$. By contrast, neutral proteases showed a significant similarity with acid, and also with basic, proteases $(p<0.05)$.

\section{Discussion}

In this study, we have presented for the first time, a complete molecular and biochemical characterization of Trichoderma strains isolated from a Brazilian agroecosystem. We believe that this approach should be used to select potential candidates for commercial biological control against Sclerotinia sclerotiorum. Generally, Trichoderma strains are identified using morphological and molecular techniques. However, elucidation of the biodiversity of Trichoderma has demonstrated that single isolated tools are insufficient to explain genus diversity, particularly within Trichoderma asperellum and Trichoderma harzianum (Kubicek et al. 2003; Hoyos-Carvajal et al. 2009). Thus, molecular and biochemical tools have become mandatory for accurate taxonomy. Here, we have identified five different Trichoderma species, mainly T. asperellum and T. harzianum, but also Trichoderma tomentosum. Our results are in accordance with those of other recent studies, which have demonstrated a high biodiversity of Trichoderma in neotropical regions, with $\mathrm{T}$. asperellum and T. harzianum as the most frequent species (Kubicek et al. 2008; Hoyos-Carvajal et al. 2009; Anees et al. 2010).

Molecular identification may be difficult, particularly when using only sequences from public data banks such as GenBank, which holds misidentified sequences. In the present study, species identification was supported by a specific database and software, recognized as reliable and advantageous for the identification of new species (Druzhinina et al. 2005). Among the 21 strains, only six strains (three isolates of $\mathrm{T}$. harzianum and three isolates of $\mathrm{T}$. tomentosum) could not be identified using TrichOKEY 2.0. However, these were identified by TrichoBLAST, coupled with phylogenetic analysis (Fig 1). Our data emphasize the need for complementary tools to confirm species identification.

The diversity of Trichoderma species, and in particular of T. harzianum, was clearly reflected in their metabolic profiles. Trichoderma harzianum could be grouped with Trichoderma erinaceum and Trichoderma koningiopsis, and also with T. tomentosum. Furthermore, T. tomentosum 476/02 could be grouped with T. asperellum (as the only two isolates to metabolize D-melezitose in the Biolog FF Microplate analysis). Hoyos-Carvajal et al. (2009) also observed this pattern and suggested the possibility of genetic interchange between $\mathrm{T}$. harzianum and $\mathrm{T}$. tomentosum. Interestingly, our data suggest a similar metabolic evolution for T. asperellum and 

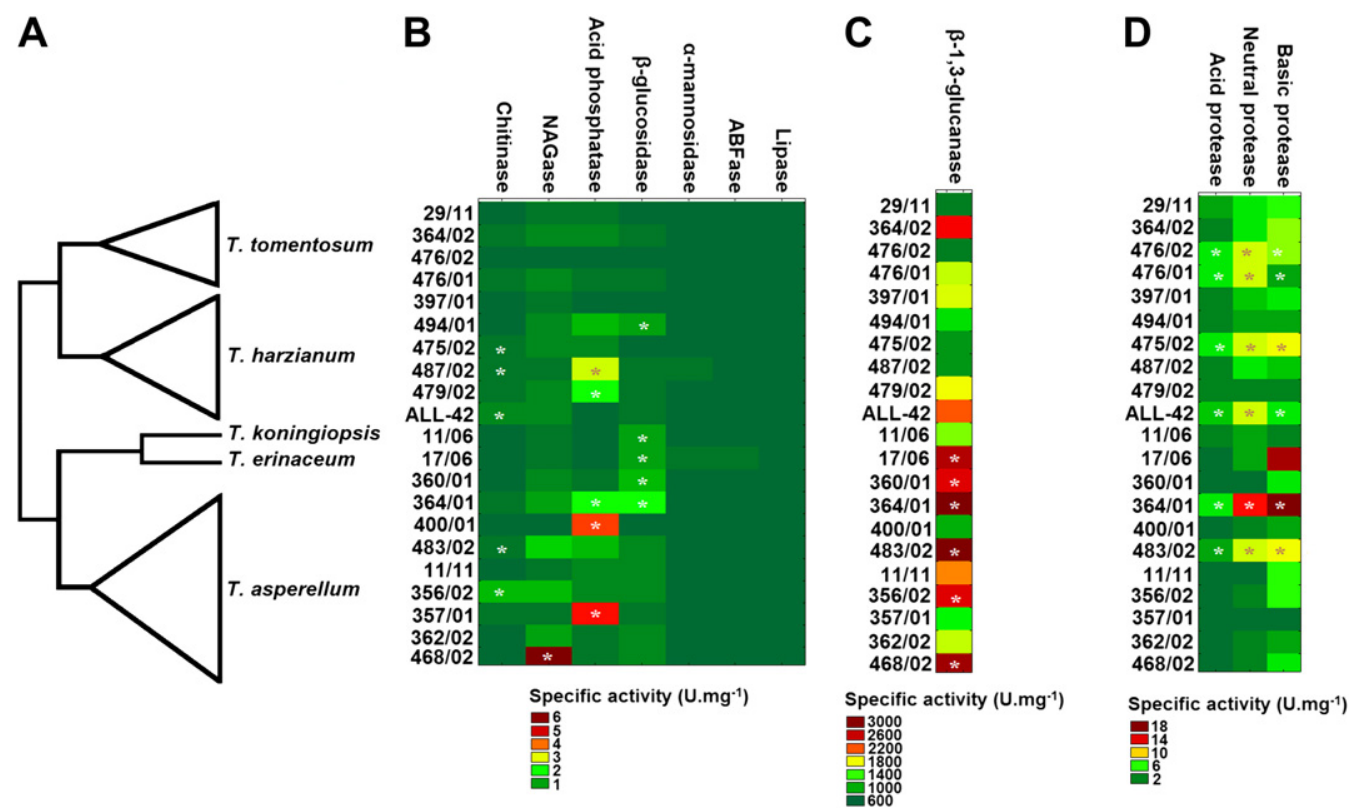

Fig 3 - Specific activities of CWDEs from strains of Trichoderma cultured on cell wall extracts of S. sclerotiorum. (A) Cladogram obtained by Bayesian analysis of tef1. (B) Specific activities of enzymes with $p$-nitrophenyl derivatives as substrates: chitinase, NAGase, acid phosphatase, $\beta$-glucosidase, $\alpha$-mannosidase, ABFase and lipase. (C) Specific activities of $\beta$-1,3-glucanase. (D) Specific activities of acid, neutral and basic proteases. All experiments were performed in triplicate; data with a mean error of $<\mathbf{2 0} \%$ are shown. Asterisks indicate the highest specific activities for each enzyme, calculated using ANOVA and the Scott-Knott test ( $\alpha=$ Cladogram $5 \%$ ).

T. tomentosum. However, genetic interchange between these two species is impossible, because of differences in their genomes (Kubicek et al. 2011). Thus, this evolution may have occurred in response to the environment.

Our metabolic data further revealed two distinct clusters for T. asperellum (Fig 2). This pattern was also observed by Hoyos-Carvajal et al. (2009), indicating a high metabolic diversity in tropical T. asperellum isolates. Using a combination of genomic, proteomic, and classical mycological techniques, Samuels et al. (2010) demonstrated that T. asperellum consists of two cryptic species-T. asperellum and Trichoderma asperelloides sp. nov. In the present study, we were unable to distinguish these two cryptic species, either by tef1 or by morphological analysis. Taken together, our findings support the idea of heterogeneity within neotropical T. harzianum and T. asperellum (Hoyos-Carvajal et al. 2009).

The use of metabolic characteristics to investigate phylogeny is increasing. The technique represents an important tool for elucidating species relationships based on ITS sequences. In particular, it may prove valuable in the screening of Trichoderma species for industrial applications (reviewed by Atanasova \& Druzhinina 2010). In the present study, we have grouped unknown Trichoderma clusters (29/11, 364/02, and 476/02) and (397/01, 479/02, and ALL-42) based on ITS and tef1 sequences, and also on phylogenetic information, into a $T$. tomentosum and a $T$. harzianum cluster, respectively. Moreover, we have identified potential T. asperellum candidates with the ability to produce $\alpha-1,4$ and $\beta-1,4$ hydrolytic enzymes, for further investigation in biomass degradation.
The key parameters for success when using Trichoderma as a biological control agent are the production of CWDEs, antibiosis, and competition for nutrients (Almeida et al. 2007). Mycoparasitism studies have generally focused on the production of chitinases, $\beta$-1,3-glucanases, and proteases (De Marco \& Felix 2002; Almeida et al. 2007; Gajera \& Vakharia 2010), all of which are closely related to the cell wall composition of the pathogen (Viterbo et al. 2002). We previously reported that other enzymes, such as phosphatases and lipases, are involved in mycoparasitism (Silva et al. 2009). Furthermore, using proteomic approaches, we recently identified a role for $\alpha$-mannosidase and ABFase in mycoparasitism (Monteiro et al. 2010). In the present study, we observed that T. asperellum exhibited the highest CWDE activity. However, no species secreted a specific group of CWDEs. Moreover, we observed a high diversity of enzyme secretion, even within the same species. This finding can be explained by the high complexity of CWDE gene regulation, with different rates of evolution and adaptation, caused by different environmental pressures.

In the present study, we have revealed specific strains as strong candidates for the biological control of S. sclerotiorum. Trichoderma asperellum 364/01, T. asperellum 483/02, and T. asperellum 356/02 showed high and medium specific activities for key enzymes in the mycoparasitic process, e.g., chitinase, NAGase, $\beta$-1,3-glucanase, and proteases. Moreover, they demonstrated a high capacity to metabolize several substrates on Biolog FF Microplates (which is important for nutrient competition), and also a high acid phosphatase specific activity. Acid phosphatase is known to play a role in the 
release of inorganic phosphate from the soil, thus making it available for use by plants (Altomare et al. 1999). Thus, the biological control of S. sclerotiorum by T. asperellum 364/01, T. asperellum 483/02, and T. asperellum 356/02 may also contribute to plant development.

Most CWDEs are inducible by substrate. Thus, the low specific activities of ABFase, $\alpha$-mannosidase, and lipase exhibited by Trichoderma strains can be explained by the small amount of the respective substrates in the S. sclerotiorum cell wall (Bartnicki-Garcia 1968). Monteiro et al. (2010) reported high levels of $\alpha$-mannosidase production by $\mathrm{T}$. harzianum in the presence of R. solani, while Silva et al. (2009) observed the same pattern for lipase production by Trichoderma reesei during mycoparasitism against Pythium ultimum. Thus, it appears that secretion of these enzymes is phytopathogen-dependent.

High production of CWDEs does not guarantee successful biocontrol by Trichoderma in the field. The process is complex, and many other factors must be considered before choosing an isolate for field application. These include the ability of Trichoderma to produce and/or resist metabolites, antibiosis, rhizosphere modification, production of toxic compounds and/or antibiotics, plant growth promotion, stimulation of plantdefence mechanisms, and, most importantly, the survival of Trichoderma in the soil environment (reviewed by Benítez et al. 2004). Almeida et al. (2007) observed no correlation between CWDE production and frequency of coiling, during the screening of Trichoderma strains for biological control of R. solani. In the present study, we revealed a significant correlation $(r>0.5 ; p<0.01)$ only between proteases, chitinase/antagonism, and glucanase/basic protease (data not shown). However, our outcomes should be treated cautiously, because of the small number of samples analyzed. Despite this limitation, the 21 isolates studied represent an important sample of the Brazilian diversity of Trichoderma, because they originated up to $1300 \mathrm{~km}$ apart, from latitudes ranging from $13^{\circ} 13^{\prime}$ to $23^{\circ} 25^{\prime}$. Thus, their diverse biochemical and metabolic profiles are likely to have been influenced by previous exposure to anthropogenic pressure in different agroecosystems. This selection pressure, in turn, may represent an advantage for conventional biological control.

In the present study, we revealed that antibiosis and antagonism against $\mathrm{S}$. sclerotiorum were not species-dependent. Different Trichoderma strains of the same species exhibited different results, and no correlation between species was observed, despite a synergism between antibiosis and antagonism. Similar results were reported by Anees et al. (2010), during characterization of field isolates of Trichoderma for antagonism against $R$. solani. In the present study, we also detected no synergistic correlation between antagonism and CWDE production (data not shown), except for chitinase. Trichoderma asperellum 364/01, T. asperellum 483/02, and T. asperellum 356/02 exhibited high CWDE production, but a low capacity for antagonism. The cause of such a mismatch between CWDE production and antagonism/antibiosis remains to be elucidated. However, a Trichoderma strain with high expression of each trait would be desirable for biological control. Furthermore, metabolic capacity appeared not to be correlated with antagonism, because the best antagonists in the plate tests (ALL42, 11/11, and 29/11) showed different profiles in the Biolog FF Microplate analysis (blue rectangles on
Fig 2). Taken together, these findings indicate the complexity of events that occur during biological control by Trichoderma.

In an attempt to develop a rapid screening system for biocontrol-competent strains of Trichoderma, Scherm et al. (2009) used subtraction hybridization to identify specific genes for use as markers. However, even in these groups of genes, the antagonistic activity appeared to be related to the efficiency of gene expression in the presence of the host, indicating diversity even within a species. These findings further confirm that the selection of candidates for biological control should be based primarily on the environmental fitness of competitive isolates and also on the type of pathogenic challenge rather than on the use of specific Trichoderma species. Thus, we propose that a combination of different Trichoderma species and strains, with different antagonistic and mycoparasitic characteristics, should be used for commercial biological control. Most importantly, strains should be previously tested for adaptation to the agroecosystem in which they will be applied. Thus, the development and use of a universal product for biological control requires extensive further research.

In the present study, we have successfully used molecular, enzymatic, and metabolic analyses to identify potential Trichoderma strains for use in the biological control of S. sclerotiorum. We have further demonstrated that CWDEs represent important tools for the identification of promising candidates for biological control. Our data, when combined with the results of field testing (currently underway), will be crucial to the selection of Trichoderma strains for more efficient formulations for the control of fungal pathogens.

\section{Acknowledgements}

This work was funded by FINEP (Research and Projects Financing), and the National Council for Scientific and Technological Development (CNPq) (FINEP/CT-AGRO/01.07.0551.00/ Ref. 0845/07). F.A.C.L is supported by CAPES fellowship. C.J.U is supported by a biotechnology research grant (CNPQ), FAPEGO and FUNAPE (proc. 20081026700108). R.N.S is supported by The State of São Paulo Research Foundation (FAPESP) (proc. 2010/15683-8).

\section{Appendix A. Supplementary material}

Supplementary material associated with this article can be found, in the online version, at doi:10.1016/j.funbio.2012.04.015.

\section{R E F E R E N C E S}

Almeida FB, Cerqueira FM, Silva RN, Ulhoa CJ, 2007. Mycoparasitism studies of Trichoderma harzianum strains against Rhizoctonia solani: evaluation of coiling and hydrolytic enzyme production. Biotechnology Letters 29: 1189-1193.

Altomare C, Norvell WA, Björkman T, Harman GE, 1999. Solubilization of phosphates and micronutrients by the plantgrowth-promoting and biocontrol fungus Trichoderma 
harzianum Rifai 1295-22. Applied and Environmental Microbiology 65: 2926-2933.

Anees M, Tronsmo A, Edel-Hermann V, Hjeljord LG, Héraud C, Steinberg C, 2010. Characterization of field isolates of Trichoderma antagonistic against Rhizoctonia solani. Fungal Biology 114: 691-701.

Atanasova L, Druzhinina IS, 2010. Clonal species Trichoderma parareesei sp. nov. likely resembles the ancestor of the cellulase producer Hypocrea jecorina/T. reesei. Applied and Environmental Microbiology 76: 7259-7267.

Bartnicki-Garcia S, 1968. Cell wall chemistry, morphogenesis and taxonomy of fungi. Annual Review of Microbiology 22: 87-108.

Bell DK, Wells HD, Markham CR, 1982. In vitro antagonism of Trichoderma species against six fungal plant pathogens. Phytopathology 72: 379-382.

Benítez T, Rincón AM, Limón MC, Codón AC, 2004. Biocontrol mechanisms of Trichoderma strains. International Microbiology 7: 249-260.

Bradford MM, 1976. A rapid and sensitive method for the quantitation of microgram quantities of protein utilizing the principle of protein-dye binding. Analytical Biochemistry 72: 248-254.

De Marco JL, Felix CR, 2002. Characterization of a protease produced by a Trichoderma harzianum isolate which controls cocoa plant witches' broom disease. BMC Biochemistry 3: 1-7.

Druzhinina IS, Kopchinskiy AG, Komon M, Bissett J, Szakacs G, Kubicek CP, 2005. An oligonucleotide barcode for species identification in Trichoderma and Hypocrea. Fungal Genetics and Biology 42: 813-828.

Druzhinina IS, Kubicek CP, Komoń-Zelazowska M, Mulaw TB, Bissett J, 2010. The Trichoderma harzianum demon: complex speciation history resulting in coexistence of hypothetical biological species, recent agamospecies and numerous relict lineages. BMC Evolutionary Biology 10: 94.

Druzhinina IS, Schmoll M, Seiboth B, Kubicek CP, 2006. Global carbon utilization profiles of wild-type, mutant, and transformant strains of Hypocrea jecorina. Applied and Environmental Microbiology 72: 2126-2133.

Druzhinina IS, Seidl-Seiboth V, Herrera-Estrella A, Horwitz BA, Kenerley CM, Monte E, Mukherjee PK, Zeilinger S, Grigoriev IV, Kubicek CP, 2011. Trichoderma: the genomics of opportunistic success. Nature Reviews Microbiology 16: 749-759.

Elad Y, Chet I, Boyle P, Henis Y, 1983. Parasitism of Trichoderma harzianum spp. on Rhizoctonia solani and Sclerotium rolfsii. Scanning microscopy and fluorescence microscopy. Phytopathology 73: 85-88.

Gajera HP, Vakharia DN, 2010. Molecular and biochemical characterization of Trichoderma isolates inhibiting a phytopathogenic fungi Aspergillus niger Van Tieghem. Physiological and Molecular Plant Pathology 74: 274-282.

Hoyos-Carvajal L, Orduz S, Bissett J, 2009. Genetic and metabolic biodiversity of Trichoderma from Colombia and adjacent neotropic regions. Fungal Genetics and Biology 46: 615-631.

Jaklitsch WM, Komon M, Kubicek CP, Druzhinina IS, 2006. Hypocrea crystalligena sp. nov., a common European species with a white-spored Trichoderma anamorph. Mycologia 98: 499-513.

Komada H, 1975. Development of a selective medium for quantitative isolation of Fusarium oxysporum from natural soil. Review of Plant Protection Research 8: 114-125.

Kubicek CP, Bissett J, Druzhinina I, Kullnig-Gradinger C, Szakacs G, 2003. Genetic and metabolic diversity of Trichoderma: a case study on South-East Asian isolates. Fungal Genetics and Biology 38: 310-319.
Kubicek CP, Komon-Zelazowska M, Druzhinina IS, 2008. Fungal genus Hypocrea/Trichoderma: from barcodes to biodiversity. Journal of Zhejiang University Science B 9: 753-763.

Kubicek CP, Herrera-Estrella A, Seidl-Seiboth V, Martinez DA, Druzhinina IS, Thon M, Zeilinger S, Casas-Flores S, Horwitz BA, Mukherjee PK, Mukherjee M, Kredics L, Alcaraz LD, Aerts A, Antal Z, Atanasova L, Cervantes-Badillo MG, Challacombe J, Chertkov O, McCluskey K, Coulpier F, Deshpande N, von Döhren H, Ebbole DJ, Esquivel-Naranjo EU, Fekete E, Flipphi M, Glaser F, Gómez-Rodríguez EY, Gruber S, Han C, Henrissat B, Hermosa R, Hernández-Oñate M, Karaffa L, Kosti I, Le Crom S, Lindquist E, Lucas S, Lübeck M, Lübeck PS, Margeot A, Metz B, Misra M, Nevalainen H, Omann M, Packer N, Perrone G, Uresti-Rivera EE, Salamov A, Schmoll M, Seiboth B, Shapiro H, Sukno S, Tamayo-Ramos JA, Tisch D, Wiest A, Wilkinson HH, Zhang M, Coutinho PM, Kenerley CM, Monte E, Baker SE, Grigoriev IV, 2011. Comparative genome sequence analysis underscores mycoparasitism as the ancestral life style of Trichoderma. Genome Biology 12: R40.

Kullnig-Gradinger CM, Szakacs G, Kubicek CP, 2002. Phylogeny and evolution of the fungal genus Trichoderma-a multigene approach. Mycology Research 106: 757-767.

Monteiro V, Nascimento SR, Steindorff A, Costa F, Noronha E, Ricart C, de Sousa M, Vainstein M, Ulhoa C, 2010. New insights in Trichoderma harzianum antagonism of fungal plant pathogens by secreted protein analysis. Current Microbiology 61: 298-305.

Raeder U, Broda P, 1985. Rapid preparation of DNA from filamentous fungi. Letters Applied Microbiology 1: 17-20.

Ramada MHS, Lopes FAC, Ulhoa CJ, Silva RN, 2010. Optimized microplate $\beta$-1,3-glucanase assay system for Trichoderma spp. screening. Journal of Microbiological Methods 81: 6-10.

Reithner B, Brunner K, Schuhmacher R, Peissl I, Seidl V, Krska R, Zeilinger S, 2005. The G protein alpha subunit Tga1 of Trichoderma atroviride is involved in chitinase formation and differential production of antifungal metabolites. Fungal Genetics and Biology 42: 749-760.

Samuels GJ, Ismaiel A, Bon MC, De Respinis S, Petrini O, 2010. Trichoderma asperellum sensu lato consists of two cryptic species. Mycologia 102: 944-966.

Scherm B, Schmoll M, Balmas V, Kubicek CP, Migheli Q, 2009. Identification of potential marker genes for Trichoderma harzianum strains with high antagonistic potential against Rhizoctonia solani by a rapid subtraction hybridization approach. Current Genetics 55: 81-91.

Seidl V, Song L, Lindquist E, Gruber S, Koptchinskiy A, Zeilinger S, Schmoll M, Martínez P, Sun J, Grigoriev I, Herrera-Estrella A, Baker SE, Kubicek CP, 2009. Transcriptomic response of the mycoparasitic fungus Trichoderma atroviride to the presence of a fungal prey. BMC Genomics 10: 567.

Silva RN, Steindorff AS, Ulhoa CJ, Félix CR, 2009. Involvement of Galpha protein GNA3 in production of cell wall-degrading enzymes by Trichoderma reesei (Hypocrea jecorina) during mycoparasitism against Pythium ultimum. Biotechnology Letters 34: 531-536.

Viterbo A, Ramot O, Chemin L, Chet I, 2002. Significance of lytic enzymes from Trichoderma spp. in the biocontrol of fungal plant pathogens. Antonie Van Leeuwenhoek 81: 549-556.

White TJ, Bruns T, Lee S, Taylor J, 1990. Amplification and direct sequencing of fungal ribosomal RNA genes for phylogenetics. In: Innis MA, Gelfand DH, Sninsky JJ, White TJ (eds), PCR Protocols: a guide to methods and applications. Academic Press, New York, pp. 315-322. 